\title{
Application of the EKD Process Model to Support the Coordination of Collaborative Networks in the Civil Construction Sector
}

\author{
Flávia Vancim Frachone Neves and Fábio Müller Guerrini \\ São Carlos Engineering School (USP) - Production Engineering Department \\ Trabalhador Sãocarlense Avenue, nº 400, Zip Code 13566-590 São Carlos, Brazil \\ frachoneasc.usp.br, guerriniasc.usp.br
}

\begin{abstract}
The civil construction industry has an operation way similar to virtual organizations, but in not structuralized form, leaving to provide competitive advantages. For in such a way, the paper will propose, through analytical research and case studies and based on EKD (Enterprise Knowledge Development) methodology, the Process Model to support the coordination of collaborative networks in the civil construction sector. This model will analyze each process and information flow contained in the business, that is, describes in a structuralized form the organizational activities, so that promoting better understanding of how the processes could be done to support companies of civil construction sector.
\end{abstract}

Keywords: Collaborative Networks, Civil Construction, EKD Process Model.

\section{Introduction}

Under a general background, [1] and [2] defends that the civil construction industry occupies strategically position in the generation of jobs, mainly of low qualification, and that it starts to demonstrate continuous effort for process improvement with the use of partnerships among companies. On the other hand [3], [4], [5], [6], [7] and [8] displays that it has low degree of innovation, communication, confidence, coordinate cooperation, the culture steel conservative and the majority of the works, as [9] affirms, are organized in unique projects.

A success partnership does not occur itself. For [10], [11] and [8] affirms that develop shared relationship reliable, equality or benefits, communication accomplishes and competent management, is difficult and these are critical factors. Therefore, is possible to affirm that the construction partnership is surrounded of high risks and profits. The main factor for partnership in the construction projects is, according to [1], the benefit to share the risk among the parts. With bigger projects, a unique firm could not obtain all necessary resources. Already through the partnership, the construction companies can combine resources and abilities.

Due to the advantages cited above, this paper proposes, based on EKD (Enterprise Knowledge Development) methodology, the Process Model to support the coordination of collaborative networks in the civil construction sector. 


\section{Research Method}

In accordance with [12], the organizational modeling methodology EKD (Enterprise Knowledge Development) provides to the involved ones in the project to have more analytical organization optics and its components as a whole, through the organizational modeling. The EKD composition, continuing in accordance with [12], through the use of the EKD, a clear and not ambiguous description can be promoted of how the organization functions; which the requirements and reasons for change; which alternatives must be created to find these requirements and which criteria and arguments for evaluation of these alternatives. Also, some of the most important benefits offered by EKD, which: better understand the business; facilitate the organizational learning and communication and assist the agreement of the organization processes.

Ahead of the displayed context, and to fulfill with the research goal it will be presented a qualitative analysis of the organizational aspects of virtual nets among civil construction partners. The used method will be given by means of approach bibliographical research, searching a problem from theoretical references, of qualitative character, propitiating bigger proximity of the researcher with the problems studied beyond the analysis of the searched context, and exploratory, giving correlations between study objects to collaborative with future research. The analytical research, in accordance with [13], prevents the duplicity of knowledge and, it gets theoretical recital for the work development. The empirical study was divided on phases. The first one, evidence collection, was composed of documents of four construction workmanships, of two Brazilian constructions companies both acting in national level, and interviews with their managers. These numbers of cases, in accordance with [14] and [13], supply convincing base for an initial set of proposals.

The second phase, chaining of the collected data, was composed based on after data collected and refined, some information had to be confirmed, with its respective ones interviewed, in order to cure eventual doubts of the researchers and, therefore, to chain the collected and observed evidences, to give pursuing to the following and final stage, which was Modeling the Process Model. Once the data collected, refined, validated and chained, the model considered was shaped.

The interviewed ones were responsible for workmanships management. The research was made under the analytical clipping of virtual nets, in elapsing of seven months, year of 2009. Inside of this context, the general questions that the studies had been considered to enclose corresponded to clarify: why is necessary modeling the processes of virtual nets among civil construction partners; what organizational levels should be suggested to be involved in the network among civil construction partners; and which are the detailing levels that the model should reach to solve the necessities and to correspond to the expectations of the studied economic sector.

\section{Data Analysis}

During six months were analyzed four civil construction workmanships of two Brazilian constructors, and interviewed the responsible for workmanships management through meetings and, later, at a distance (using the Internet as communication way). 
This process was made using half-structuralized questionnaire, which was divided in three stages, as mentioned subsequently.

On first stage, companies characterization, it is import to remember that both companies have a familiar structure, acts in national levels, and the interviewed ones where workmanships managers. The companies analyzed will be called here: "Company A" and "Company B".

Specifically about Company A, founded at year of 1966, could be observed that it generates about a thousand jobs and acts in different types of workmanships, like: houses and residential buildings of high standard; educational, commercial and industrial buildings. In addiction, the high professionals are stimulated to improve the knowledge through partnership with academic institutions.

From Company B, founded at year of 1996, could be observed that it generates about two hundred and sixty five jobs and acts in different types of workmanships, like: houses and residential buildings of high standard; intelligent houses (all spaces using the high technology); commercial buildings and logistical condominiums. Besides the workmanships employees have extra benefits, extended to his family, that stimulate them to keep satisfy in company. In the same way, the high employees (engineering, managers, directors for example) where stimulated to improve their knowledge through specializations in academic institutions.

On second stage, companies operation's way, during the interview's meetings could be observed that both companies studied had the same characteristics in operation's ways, as observed subsequently.

The partnership use to be more frequently, and for long time, among company and workmanship's projectors. In this case, is more difficult to change the partners due to the fact that the work executed from them has a high level of costs and specificities. Also, it is important to say that the companies used to be afraid to test new workmanship's projectors and besides, do not stimulate the intercommunication among these partners.

With suppliers (materials or services), the partnership use to has a short period, due to the fact that companies are more receptive to test new suppliers until they gains confidence in definitive. While this, it is usual happens problems of not fulfillment of stated periods, inferior quality of materials and services, among other things. Such occurrences are not registered, consequently do not exist performance registers of any supplier partner.

Beyond the use of tools/software as publishers of text and spread sheets, do not have another tool/software for aid to the management of the workmanships used by the company. Also, time and money are usually wasted due to the unfamiliarity of the partners and absence of register of its respective behaviors, by the companies, in elapsing of the workmanship where they participate.

Finally on third stage, workmanship analysis, the four workmanships analyzed where: a logistic condominium (finished); a high level residence building (almost finished); and two commercial buildings (one in planning phase and another under initial construction phase).

From the Logistic Condominium could be noted that the company made the workmanship in another State and because of this, they had a high level of difficulty in found partners. This brought some problems to the workmanship like: delay of the 
stipulated time to build, due to the time wasted in found the partners; changing some partners in the middle of the construction phase due to the low qualification of them; waste of materials and a constant changing's financial chronograms.

The High Level Residence Building had problems related to task's delay. Besides, the initial projects did not match with the task's executions, due to the lack of communication among projectors. But, it is important to remember that workmanships like this had the special characteristic that the final clients possess a level of decision in construction's final phase, contributing to delay the conclusion.

The other two workmanships, the commercials buildings at initial phases: one of them, in the planning phase, was having problems because the city hall's licenses were taking a long time to be approved and the operational partners were been paid without executing the service. This mistake was occurring due to the lack of initial planning of time and in having alternatives actions in case of occur unexpected actions like this. The other commercial building, in initial phase of construction, had problems just related to the difficulty of founding some specific suppliers to execute some specific construction's services in some phases.

Due to these facts, this article will propose, in the next section, a Process Model based on EKD methodology as a first step to support the coordination of cooperation networks among civil construction partners.

\section{Result - The Process Model}

Considering the analytical view made by the authors, this section will propose the Process Model, figure 1, in order to help companies to coordinate its partnerships through the workmanships phases.

As can be noted subsequently, from figure 1, the process of evaluate possibility of new workmanship (Process 1 ) began with a possibility of new workmanships possibilities (Inf. 0). This process signalized the possibility to invest (Inf. 1), which starts the next process of defining the workmanship broker (Process 2). With this paper defined (Inf. 2), starts the bureaucratic/strategic procedures (Process 3), which makes all workmanship planning (Inf. 3). That refers to approving workmanship's licenses in the City Hall (Process 3.1), analyze and choose the workmanship's projectors (Process 3.2) and suppliers (Process 3.3). At the same time, it's important to remember that projectors must congregate (Process 3.2.1) to know each other project (Inf. 3.2.1). Concomitantly the chronograms (activities, time and cost) must be defined (Process 3.4).

When projectors and suppliers are founded (Inf. 3.2 and 3.3 respectively), it's time to elaborate/review the contract (Process 4) in order to have the workmanship's clauses signed (Inf. 4).

With the licenses approved (Inf. 3.1), suppliers founded (Inf. 3.3), contract signed (Inf. 4) and projectors knowing each other (Inf. 3.2.1), the workmanship can be executed/reconfigured (Process 5).

With goals reached (Inf. 5), the workmanship is finished (Process 6) and the performance of all partners are measured (Inf. 6). 


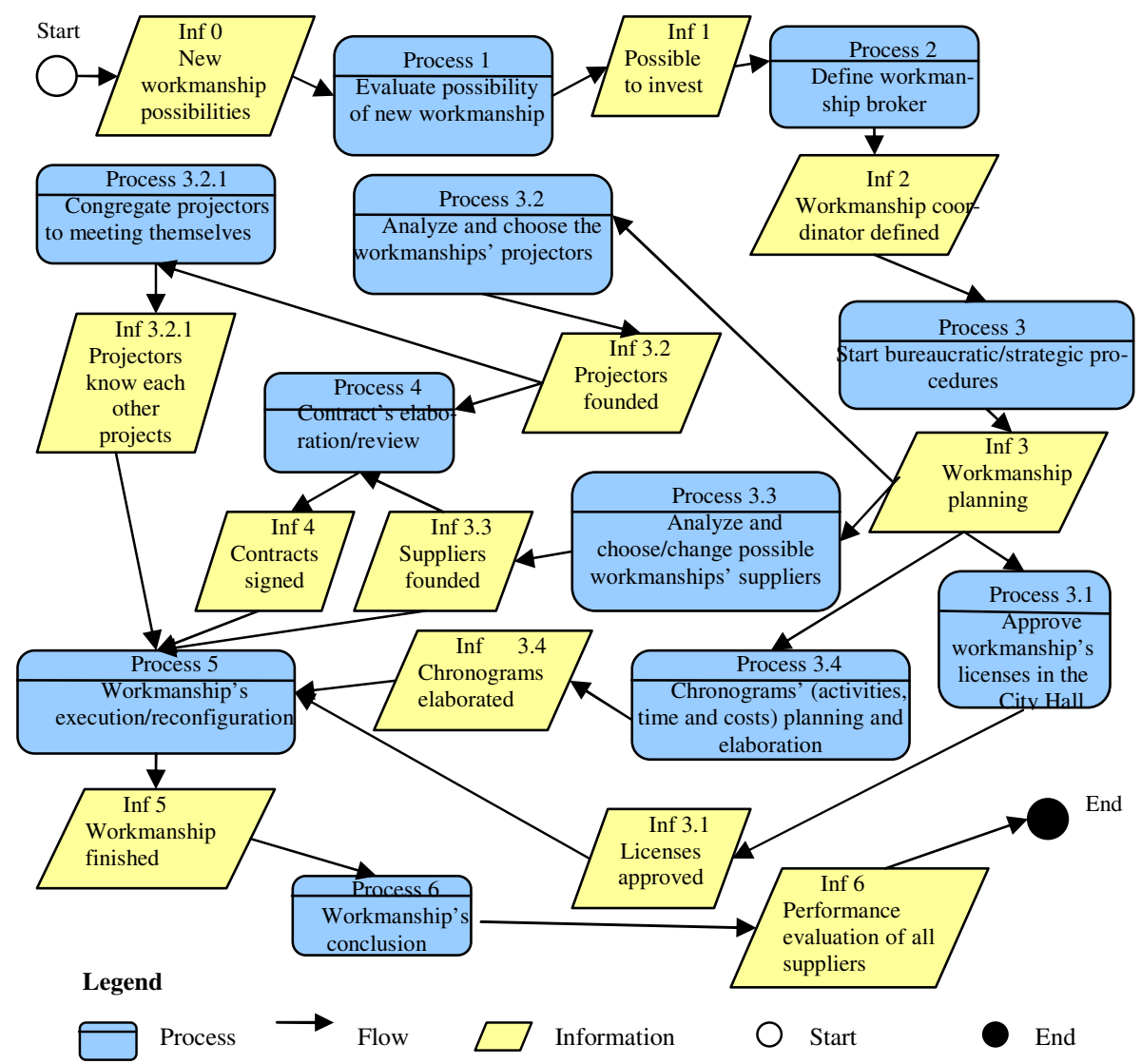

Fig. 1. The Process Model to Coordinate Networks among Workmanships Partners

As referenced by [15], [6], [16] and [17], is necessary that the companies keep in permanent change and improvement. Also, competitiveness make companies constantly look for new advantages opportunities. These proposals had delimitated Process 1 (Evaluate possibility of new workmanship).

Once the market opportunities detected, next step is select a workmanship broker, that defines the resources, capabilities and abilities necessary to execute the workmanship. On this context [18] affirm that broker manages the dynamic net, also serving as facilitator, coordinator and moderator among partners. Due to the importance of this actor, the Process 2 (Define workmanship broker) was defined.

With the workmanship facilitator defined, the company, as mentioned by [17], must carry through the procedures that must be followed. This refers to Process 3 (Start bureaucratic/strategic procedures) and consequently Process 3.1 (Approve workmanship's licenses in the City Hall).

Concomitantly, it's necessary to verify witch partners are apt or not to participate in the workmanship. The main factor for partnership in the construction projects is, according to [1], the benefit to share risk and focus on core competencies. Based on 
this, Process 3.2 (Analyze and choose the workmanships' projectors) and Process 3.3 (Analyze and choose/change possible workmanships' suppliers) where defined.

As [10] approach that the involved parts in the construction partnership must meet before workmanship execution, and argue the specific procedures of the Project, like Process 3.2.1 (Congregate projectors to meeting themselves) demonstrate. After this phase, creates the teams of cooperation and development of the business relationship. Additionally, so that this partnership is formed, it is necessary that all partners understand the goals clearly.

As [8] affirms, construction partnership is surrounded of high risks and profits. Therefore, and after choosing partners, it's crucial to define and register partnership clauses that will guarantee the fulfillment of the agreement. This important factor defined the Process 4 (Contract's elaboration/review).

When the bureaucratic procedures are done and partners defined, the workmanship is operated. On this phase, as cited by [19], the workmanship are playing the business processes in order to reach the common goals established. In addiction, there are cases where some partners must be replaced or reconfigured. This motivated the Process 5 (Workmanship's execution/reconfiguration).

Steal in accordance with [19], once the workmanship's goals are reached, the project is finalized and partnership dissolution. This motivated the Process 6 (Workmanship's conclusion).

\section{Conclusion}

Treating on the Brazilian civil construction industry, could be detached the changes resistance and conservative culture. On this way, the article considered the adoption of the modeling methodology EKD, due its facility in understanding the functioning of the business stimulating the involvement and active participation of all stakeholders. Beyond this, develops a business process description.

Also, it's important to point out that the chosen method independent of specific tool for development. This becomes the proposal highly viable, a time that drastic investments in tools for orientation of the coordination of the organization are not well accepted for the investors. In addiction, the EKD methodology allows stakeholders to easily visualize which organizational changes are necessary to be carried through in order to take care of the goals stipulated. Also, the Process Model proposed by this article, the methodology propitiates the necessary steps and alternative ways to execute some strategy. On this case, it refers to which process must be executed/done to coordinate a network among workmanships partners.

Moreover, it's important to remember that the actions of evaluating the partners makes possible to the directors and decision makers having the necessary information to support the process of chosen partners in future workmanships, based on his past behavior, what probably will increase the partners' commitment with the company due to the fact that they have interest in continuing working. Finally, and continuing with suggestible future research, it must be empathized that: the lacks of communication on workmanships' planning phase presents unsustainable actions that, consequently, damage, even so, our ecosystem. This occurs due to the fact that this lacks of communication causes, among other things, waste of material on workmanships' 
execution that is discarded on City Halls Garbage and not recycled. So, another possible future research must also treat the question of sustainability in workmanships.

\section{References}

1. Black, C., Akintoye, A., Fitzgerald, E.: An Analysis of Success Factors and Benefits of Partnering in Construction. International Journal of Projects Management 18, 423-434 (2000)

2. Lima, C., Stephens, J., Böhms, M.: The BCXML: Supporting Ecommerce and Knowledge Management in the Construction Industry. In: Itcon 2003, vol. 8 (2003)

3. Brightman, J.R., Eden, C., Heijden, K.V.D., Langford, D.A.: The Development of the Construction Alternative Futures Explorer. Automation in Construction 8, 613-623 (1999)

4. Wilson, I., Harvey, S., Vankeisbelck, R., Kazi, A.S.: Enabling the Construction Virtual Enterprise: the OSMOS Approach 2001, vol. 6 (2001),

http: / /www. itcon. org/2001/8 (consulted on December, 01,2005)

5. Cheng, E.W.L., Li, H.: Construction Partnering Process and Associated Critical Success Factors: Quantitative Investigation. Journal of Management in Engineering, 194-201 (October 2002)

6. Chan, A.P.C., Chan, D.W.M., Chiang, Y.R., Tang, B.S., Chan, E.H.W., Ho, K.S.K.: Exploring Critical Success Factors for Partnering in Construction Projects. Journal of Construction Engineering and Management, 188-197 (March/April 2004)

7. Holmen, E., Pedersen, A.C., Torvatn, T.: Building relationships for technological innovation. Journal of Business Research 58, 1240-1250 (2005)

8. Wong, P.S.P., Cheung, S.O., Ho, P.K.M.: Contractor as Trust in Construction Partnering Prisoner's Dilemma Perspective. Journal of Construction and Management, 1045-1053 (October 2005)

9. Zarli, A., Richaud, O.: Requirements and Technology Integration for It- Based BusinessOriented Frameworks in Building and Construction. In: Itcon 1999, vol. 4 (1999)

10. Glagola, C.R., Sheedy, W.M.: Partnering on Defense Contracts. Journal of Construction Engineering and Management, 127-138 (March-April 2002)

11. Rahman, M., Kumaraswamy, M.: Relational Selection for Collaborative Working Arrangements. Journal of Construction Engineering and Management, 1087-1097 (October 2005)

12. Bubenko, J.Á., Brash, D., Stirna, J.: EKD User Guide. Department of Computer and Systems Sciences. Royal Institute of Technology, Stockholm (1998)

13. Yin, R.K.: Case Study Research: Design and Methods, 3rd edn. Sage Publications, Inc., California (2003)

14. Herriot, R.E., Firestone, W.A.: Multisite qualitative policy research: optimizing description and generalizability. Educational Research 12, 14-19 (1983)

15. Belusi, F., Arcangeli, F.: A Typology of Networks: Flexible and Evolutionary Firms. Research Policy 27, 415-428 (1998)

16. Matthews, J.: The rise of the virtual company. Supply Management 9, 15 (2004)

17. Jones, O.: Managing public-private partnerships: the enactment of a business venture. Technovation 25, 587-597 (2005)

18. Manring, S.L., Moore, S.B.: Creating and Managing a Virtual Inter-Organizational Learning Network for Greener Production: a conceptual model and case study. Journal of Cleaner Production, 1-9 (2006)

19. Camarinha-Matos, L., Afsarmanesh, H.: Infrastructures for Virtual Enterprises - Network Industrial Enterprises. In: Working Conference for Virtual Enterprises (PRO-VE) (October 1999) 